\title{
WATER RESERVOIRS UNDER CONSTRUCTION AS A RESULT OF THE ACTIVITIES OF “KONIN" AND “ADAMÓW" BROWN COAL MINES
}

\author{
Mirosława Gilewska', Krzysztof Otremba' \\ 1 Section of Reclamation, Department of Soil Science and Reclamation, Poznań University of Life Sciences, \\ Brzozowa 51, 62-500 Konin, Poland, e-mail: katrekult@wp.pl
}

Received: 2015.09 .16

Accepted: 2015.10.06

Published: 2015.11.10

\begin{abstract}
Post-exploitation opencast pits constitute a final stage of mining activities and turning them into public utility facilities is taking place now by their water reclamation. They constitute basins without outflows with the depth of 15 to $69 \mathrm{~m}$ and areas ranging from 2.5 to 692 ha. The bottoms of these basins are situated in pyrite-containing Miocene formations. Products of $\mathrm{Fe}_{2} \mathrm{~S}$ weathering comprise sulphuric acid and iron compounds - sulphate II and sulphate III. This study presents the basic parameters of the reservoirs constructed in the final opencast pits of the "Konin" and "Adamów" brown coal mine,s as well as the properties of the formations making up the bottoms of two water reservoirs under construction: Lubstów and Władysławów. It is evident from the performed investigations that these formations are characterised by very acid reaction and very high exchangeable acidity. The total sulphur content ranges from 446 to $962 \mathrm{mg} \cdot \mathrm{kg}^{-1}$ of the ground and that of sulphate sulphur - from 71 to $187 \mathrm{mg} \cdot \mathrm{kg}^{-1}$ of the ground. The chemism of these grounds will exert influence on the quality of water accumulating in the opencast pits during the initial period of their spontaneous flooding. Together with the increase of the capacity of these reservoirs, the contact of waters with boulder clays of the Warta River glaciation abounding in calcium compounds will increase and concentrations of calcium ions in the waters of the reservoirs will also grow.
\end{abstract}

Keywords: post-exploitation opencast pits, floor layer, Miocene sediments, pyrite, water reclamation.

\section{INTRODUCTION}

In the wake of the exhaustion of lignite resources, "Konin" and "Adamów" brown coal mines terminated exploitation of this resource in nine open cast mines leaving behind external and internal dumping grounds as well as opencast pits. Post-exploitation pits constitute a final phase of mining activities and can be described as interior basins from 15 to $69 \mathrm{~m}$ deep and from 2.5 to 692 ha area. The opencast pits are currently given some functional values by means of water reclamation, which includes the development of water reservoirs.

The process of filling opencast pits with water takes place spontaneously as a result of restoration of hydrostatic pressures within the area of the depression funnel. This process can take 40 to 50 years. In order to shorten the time of opencast pit filling, also waters derived from the drainage of active opencast mines are pumped into it. About $75 \%$ of waters pumped by "Konin" and "Adamów" mines come from the tertiary or tertiarycretaceous horizons.

However, the research results presented in this study are not associated with special investigations conducted within the framework of hydrological conditions. They deal with the properties of grounds constituting the bottoms of the bowls of water reservoirs. They are determined by the floor of deposition of coal deposits. They are situated in Miocene formations which consist of coal-containing fine-grain sands also incorporating iron disulfides represented mainly by pyrite. Tertiary rocks are also found abundantly in bottom portions of opencast pits. Their slopes are 
situated both in indigenous formations as well as in post-mining materials. Weathering products of iron disulfides include sulphuric acid and iron compounds (sulphate II and sulphate III) as well as hydrogen sulphide $[1,6]$. In reclamation practice, materials containing iron disulfides are treated as toxic formations $[2,3]$.

\section{MATERIAL AND METHODS}

The paper presents basic parameters of the existing water reservoirs as well as those presently under construction in the final opencast pits belonging to "Konin" and "Adamów" brown coal mines. The floors of the following two opencast pits were subjected to special investigations: Lubstów open cast pit which ended its activities in 2009 and which belongs to the "Konin" brown coal mine and Władysławów opencast pit which belongs to the "Adamów" brown coal mine, where the exploitation of brown coal was terminated in 2012.

Samples for analyses were collected randomly from the top layer damaged by mining works. The following parameters were determined in them:

- texture with the assistance of the aerometric method,

- reaction in $\mathrm{H}_{2} \mathrm{O}$ and $\mathrm{KCL}$ in $1 \mathrm{~mol} \cdot \mathrm{dm}^{-3}$,

- exchangeable acidity by Kappen method,

- exchangeable aluminum aluminum using the Sokołow method,

- incandescence losses,

- content of $\mathrm{S}_{\text {org. }}$ according to the PB.58 standard,

- content of $\mathrm{S}_{-} \mathrm{SO}_{4}$ according to the PB.15 standard,

- content of total forms of metals in the extract with aqua regia using the ASS technique.

The paper presents only a part of the obtained research results.

\section{RESULTS}

The location of the bowl of the reservoir is determined by the contour of the final opencast pit. The ultimate (post-exploitation) opencast pit constitutes from $30 \%$ to $40 \%$ of the excavation area. The slopes of the opencast pit as well as the slopes of the adjacent internal dumping ground are shaped in the course of the exploitation in a way allowing water restoration. In addition, during exploitation, the areas of future beaches are also developed. Underwater slopes and bottom inclines are usually left for natural development.

In total, 8 water reservoirs situated in the postexploitation areas have already been constructed (Table 1). Three final opencast pits are subjected to water reclamation (Table 2). Water reservoirs situated in the Pątnów final opencast pit as well as 2 water reservoirs currently under construction - Lubstów and Kazimierz Płn. - will belong to the deepest water reservoirs in Wielkopolska. It is the intention of the management of the Adamów mine to connect 6 water reservoirs situated in the post-mining areas with Jeziorsko water reservoir and the Warta River (4).

The total area of the Lubstów opencast pit amounts is approximately 570 ha. The bottom datum after the termination of the exploitation amounts is $21.6 \mathrm{~m}$ asl. in the southern part and $29.0 \mathrm{~m}$ asl. - in the northern part. The depth of the opencast pit in its southern part ranges from 35 to $63 \mathrm{~m}$, while in its northern part - from 28 to $55 \mathrm{~m}$.

The opencast pit is divided by a $200 \mathrm{~m}$ wide dike which reaches the datum at its highest point of $49 \mathrm{~m}$ asl. The capacity of the water reservoir after filling it to the datum of $83 \mathrm{~m}$ asl. will amount to about 137000 thousand cubic meters and the area of the free surface of water -482 ha. The mean depth of the water reservoir will not exceed $29 \mathrm{~m}$.

Table 1. Operating water reservoirs situated in final opencast pits

\begin{tabular}{|c|l|l|c|c|c|}
\hline Mine & \multicolumn{1}{|c|}{ Opencast pit } & Name of reservoir & Area [ha] & Depth $[\mathrm{m}]$ & Capacity [thous. $\left.\mathrm{m}^{3}\right]$ \\
\hline \multirow{5}{*}{ Konin } & Morzysław & Morzysław & 2.5 & 15.0 & 20.0 \\
& Niesłusz & Jeziorko Zatorze & 18.5 & 27.0 & 148.0 \\
& Gosławice & Czarna Woda & 32.5 & 55 & 390.0 \\
& Kazimierz Płd & Kozarzew & 65.5 & $2.5-8.5$ & 2100 \\
& Pątnów & Pątnów & 346.0 & 50.0 & 83500 \\
\hline \multirow{4}{*}{ Adamów } & Bogdałów & Bogdałów & 10.8 & 10 & 549 \\
& Adamów & Przykona & 165.4 & 6.0 & 6099 \\
& Koźmin & Janiszew & 79.8 & 10.0 & 4388 \\
\hline
\end{tabular}


Table 2. Final opencast pits intended for water reservoirs

\begin{tabular}{|l|l|c|c|c|c|}
\hline \multicolumn{1}{|c|}{ Mine } & \multicolumn{1}{|c|}{ Opencast pit } & Beginning of flooding year & $\begin{array}{c}\text { Area } \\
{[\mathrm{ha}]}\end{array}$ & $\begin{array}{c}\text { Depth } \\
{[\mathrm{m}]}\end{array}$ & $\begin{array}{c}\text { Capacity } \\
{\left[\text { thous. } \mathrm{m}^{3}\right]}\end{array}$ \\
\hline \multirow{2}{*}{ Konin } & Lubstów & 2009 & 480 & $28-63$ & 137000 \\
& Kazimierz Płn & 2013 & 522 & $20-60$ & 143000 \\
\hline \multirow{2}{*}{ Adamów } & Władysławów & $2012 / 2013$ & $87-103$ & 21.5 & 23000 \\
\hline
\end{tabular}

The cubic capacity of the final opencast pit of the Władysławów opencast pit amounts to 42 million cubic meters. The bottom datums of the pit also vary and range from $65 \mathrm{~m}$ asl. in its central part to $80-83 \mathrm{~m}$ asl. in its northern and southern reaches. The capacity of the water reservoir, when it is filled to the datum of $105 \mathrm{~m}$, will attain 23300 thousand $\mathrm{m}^{3}$. The area of the free surface of water is to amount to 87 to 103 ha and the maximum depth of the reservoir will amount to $37 \mathrm{~m}$ and mean depth - to $21.5 \mathrm{~m}$. The process of filling the reservoir with water has already begun and will last until 2015. During the initial period of filling, the inflow of water to the opencast pit is in the range of $40 \mathrm{~m}^{3} \cdot \mathrm{min}^{-1}$ [10].

The thickness of sub-lignite sands of the Lubstów opencast pit varies and ranges from $20 \mathrm{~m}$ in its southern part to $100 \mathrm{~m}$ in the northern part. Their thickness also varies in the Władysławów opencast working and fluctuates from 3 to $5 \mathrm{~m}$ and their maximal thickness reaches $16.3 \mathrm{~m}$. In both cases, they are fine-grained quartz sands containing lignite substances and pyrite. Lenticles of clays and muds are also distributed irregularly in sands. Miocene formations, frequently containing sands, can be found underlying rocks of upper cretaceous.

In the course of mining work, the floor layer is loosened and the pyrite present in Miocene sediments becomes activated as a result of contact with water as well as with oxygen.
The presence of tertiary sediments in the bottom of water reservoirs under construction may affect the quality of waters. Their quality may also be influenced by strongly pulverised lignite material.

The floor layer, as evidenced by data presented in Table 3, is made up of loose and due to the presence of clays and muds, formations characterised by loamy texture can also occur in the floor layer. The soil reaction is very acid $-\mathrm{pH}$ measured in $\mathrm{H}_{2} \mathrm{O}$ ranged from 3.15 to 4.78 , in $1 \mathrm{~mol} \cdot \mathrm{dcm}^{-3} \mathrm{KCl}$ -2.73 to 4.30 (Table 4 ). The above-mentioned data indicate on-going processes of pyrite weathering and the presence of sulphuric acid. The sulphuric acid stimulates degradation of the majority of aluminosilicates present in clays and muds. High quantities of mobile aluminum $\left(\mathrm{Al}^{3+}\right)$ in the examined samples confirm activation of this process.

Mobile aluminum and exchangeable hydrogen $\left(\mathrm{H}^{+}\right)$contribute to exchangeable acidity. Exchangeable acidity fluctuates from 3.92 to 4.43 $\mathrm{cmol}(+) \mathrm{kg}^{-1}$ of the ground. These are values several times higher than in acid sand soils.

High incandescence losses (Table 4) corroborate considerable proportion in the floor layer of organic substances represented by strongly comminuted brown coal. It can undergo peptization in the presence of sulphuric acid.

Table 5 presents data illustrating the content of sulphur and its forms. The content of total sulphur varies greatly and ranges from 446 to 962

Table 3. Texture composition of ground clayey sand formations

\begin{tabular}{|c|c|c|c|c|}
\hline \multirow{2}{*}{ Sample number } & \multicolumn{3}{|c|}{ Fraction average } & \multirow{2}{*}{ Texture group } \\
\cline { 2 - 4 } & $2-0.05 \mathrm{~mm}$ & $0.05-0.002 \mathrm{~mm}$ & $<0.002 \mathrm{~mm}$ & $\mathrm{~g} \mathrm{p}$ \\
\hline Lubstów & 69 & 18 & 12 & $\mathrm{p} \mathrm{s}$ \\
2 & 89 & 8 & 3 & $\mathrm{p} \mathrm{I}$ \\
3 & 95 & 3 & 2 & $\mathrm{pg}$ \\
\hline Władysławów & 82 & 16 & 2 & $\mathrm{pl}$ \\
5 & 94 & 4 & 2 & $\mathrm{ps}$ \\
6 & 89 & 9 & 2 & $\mathrm{pl}$ \\
7 & 94 & 5 & 1 & $\mathrm{pg}$ \\
\hline
\end{tabular}


Table 4. Selected chemical properties of floor formations

\begin{tabular}{|c|c|c|c|c|c|}
\hline \multirow{2}{*}{ Sample number } & \multicolumn{2}{|c|}{$\mathrm{pH}$} & \multicolumn{2}{c|}{ Exchangeable acidity } & \multirow{2}{*}{$\begin{array}{c}\text { Incancescence } \\
\text { losses [\%] }\end{array}$} \\
\cline { 2 - 5 } & $\mathrm{H}_{2} \mathrm{O}$ & $1 \mathrm{M} \mathrm{KCL}$ & $\mathrm{Hv}$ & Alw & 3.99 \\
2 & 4.23 & 4.19 & 3.26 & 0.85 & 3.18 \\
3 & 3.15 & 2.72 & 3.11 & 0.86 & 4.72 \\
4 & 3.82 & 3.10 & 3.43 & 1.01 & 6.09 \\
\hline 5 & 4.54 & 3.92 & 3.12 & 0.98 & 5.14 \\
6 & 3.72 & 3.12 & 3.15 & 1.06 & 3.25 \\
7 & 4.41 & 3.98 & 3.17 & 1.14 & 4.78 \\
8 & 4.78 & 4.30 & 3.02 & 0.89 & 5.67 \\
\hline
\end{tabular}

$\mathrm{mg} \mathrm{kg}^{-1}$ of the ground. These values are higher than those considered by $[6,14]$, as toxic. Ground toxicity is further enhanced as a result of high concentrations of sulphate sulphur ranging from 71-187 $\mathrm{mg}^{-1} \mathrm{~kg}^{-1}$ ground. The ratio of sulphate sulphur to total sulphur remains at wide limits which range from 10.62 to 23.35. The wide scatter of results regarding sulphur content is associated with the specificity of pyrite weathering. It is a chemical as well as biological process. Sulphuric acid is formed at various stages of pyrite weathering.

Concentrations of the determined heavy metals (Table 6) are lower in comparison with the quality standard values of soils and earths assumed for the soil surface layer included in the B group of environmental science areas (farmland and forest land as well as land of residential areas - Law Gazette 165, No.1352, 2002 year).

\section{DISCUSSION}

One of the decisive criteria affecting the function of water reservoirs is the quality of water. Majority of water reservoirs already built or currently under construction on post-exploitation areas of "Konin" and "Adamów" brown coal mines are interior reservoirs. Their bottoms are made up of Miocene formations, primarily pyrite-containing sands. In the presence of water and oxygen, pyrite becomes active. As a result of the activity of pyrite present in the floor layer of Lubstów and Władysławów opencast pits, water in the abovementioned reservoirs is characterised by very acid reaction, very high concentrations of hydrogen and aluminum ions as well as high quantities of sulphur and sulphates. The sulphates comprise, primarily, iron and aluminum sulphates easily

Table 5. Sulphur content in floor formations

\begin{tabular}{|c|c|c|c|}
\hline Sample number & Sog $\left[\mathrm{mg}^{\mathrm{kg}}{ }^{-1}\right]$ & $\mathrm{S}_{-} \mathrm{SO}_{4}\left[\mathrm{mg}_{\mathrm{kg}}{ }^{-1}\right]$ & $\mathrm{S}_{-\mathrm{SO}_{4}}\left[\mathrm{~S}_{\text {og }} \%\right]$ \\
\hline Lubstów & & & 15.37 \\
1 & 800 & 124 & 15.91 \\
2 & 446 & 71 & 19.08 \\
3 & 980 & 187 & 22.34 \\
4 & 962 & 215 & 10.62 \\
\hline Władysławów & 446 & 187 & 21.37 \\
5 & 758 & 162 & 15.89 \\
7 & 560 & 89 & 23.35 \\
\hline
\end{tabular}

Table 6. Content of complete forms of metals in floor formations

\begin{tabular}{|c|c|c|c|c|c|c|c|c|c|}
\hline \multirow{2}{*}{$\begin{array}{c}\text { Sample } \\
\text { number }\end{array}$} & $\mathrm{Cu}$ & $\mathrm{Cr}$ & $\mathrm{Cd}$ & $\mathrm{Zn}$ & $\mathrm{Mn}$ & $\mathrm{Pb}$ & $\mathrm{Ni}$ & $\mathrm{Fe}$ \\
\cline { 2 - 9 } & \multicolumn{7}{|c|}{$\mathrm{mg}^{-1}$} \\
\hline 1 & 3.91 & 7.60 & 0.07 & 92.65 & 8.70 & 3.65 & 3.64 & 4656.82 \\
2 & 3.67 & 7.11 & 0.01 & 10.00 & 7.77 & 2.44 & 3.47 & 4663.32 \\
\hline 5 & 4.28 & 7.03 & 0.03 & 10.37 & 8.13 & 2.72 & 3.75 & 4755.95 \\
6 & 4.07 & 7.00 & 0.05 & 11.08 & 7.04 & 3.01 & 3.51 & 4437.91 \\
\hline
\end{tabular}


soluble in water. Their presence in Miocene sands was reported in the studies conducted by Krzaklewski et al. [1997], Katzur and Liebner [1999].

In the initial stage of spontaneous flooding of opencast pits, the chemism of the floor layer will exert influence on the quality of water accumulating in them. It is to be presumed that together with the filling process of the reservoirs, the concentrations of hydrogen and aluminum ions as well as the content of sulphates will decline. Together with the growing storage capacity of the reservoirs, the contact of waters with the higher slope portions of pits situated in the quaternary formations - mainly boulder clay of the Warta River glaciation - will increase. This rock is dominant in the overlayer of both opencast pits and is rich in calcium compounds [Ratajczak et al. 1995, Spychalski et al. 2008].

In addition, this formation is also the main constituent of the surface layer of the internal dumping grounds of these opencast pits.

It can be assumed that as a result of these contacts, concentrations of calcium ions will increase in the waters of these reservoirs. Siera [2012] reported domination of calcium and hydrogen carbonate ions in waters of the reservoirs established in the area of the "Adamów" opencast mine. Also Polak and Galiniak [2007] indicated the processes of desugarisation taking place in the Pątnów water reservoir. According to the aboveresearchers, the static nature of these reservoirs, their considerable depth and limited water circulation may pose a threat to water quality in future.

As mentioned earlier, waters derived from drainage of operating opencast mines are employed to fill the opencast pits with water. This is a rational method of utilisation of large quantities of deep waters which have to be removed from mines. According to investigations conducted by Staniszewski and Jusik [2013], waters derived from drainage of the Lubstów opencast mine contained elevated quantities of sulphates. However, pumped into the reservoirs, they do not deteriorate the quality of these waters.

The process of water restoration covers the area of approximately 2000 ha and the total capacity of water reservoirs situated in the exploitation opencast pits of "Konin" and "Adamów" brown coal mines amounts to about 3 billion cubic meters. This is a significant water reserve for the entire region of south-eastern Wielkopolska which may serve for natural, fire-fighting and recreational purposes. The quality of accumulat- ed waters is not an obstacle for the realisation of these targets.

\section{CONCLUSIONS}

1. The presence of pyrite-containing Miocene formations in the bottom of bowls of the discussed water reservoirs will exert a negative impact on the quality of collected waters only during the initial period of their spontaneous filling.

2. During the process of filling of these reservoirs by spontaneous flooding of the opencast pits as well as the discharge of drainage waters from the operating opencast mines, the contact of these waters with boulder clays of the Warta River glaciation rich in calcium compounds and making up the upper portions of slopes will increase leading to increased concentrations of calcium ions.

3. Water reservoirs which are currently under construction within the project of post-exploitation water reclamation of opencast pits of the "Konin" and "Adamów" brown coal mines will contribute to the enrichment of surface water resources in south-eastern Wielkopolska.

\section{REFERENCES}

1. Gilewska M. 1997. Rekultywacja biologiczna gruntów pogórniczych w aspekcie wietrzenia dwusiarczków żelaza. Roczn. AR Poznań. CCXCIV, Melior. Inż. Środowiska 19, I, 7-19.

2. Gilewska M., Otremba K. 2011. Geochemiczne właściwości gruntu pogórniczego zbudowanego $\mathrm{z}$ utworów mioceńskich. Nauka Przyroda Technologie, 5 (6), 106.

3. Greinert H., Drab M., Greinert A. 2009. Studia nad efektywnością leśnej rekultywacji zwałowisk fitotoksycznie kwaśnych piasków mioceńskich po byłej Kopalni Węgla Brunatnego w Łęknicy. Oficyna Wydawnicza Uniwersytetu Zielonogórskiego, Zielona Góra.

4. Kasztelewicz Z. 2010. Rekultywacja terenów pogórniczych w polskich kopalniach odkrywkowych. Monografia. Fundacja Nauka i Tradycje Górnicze z siedzibą Wydział Górnictwa i Geoinżynierii AGH, Kraków.

5. Katzur J., Liebner F. 1999. Untersuchungen zum Einflub mikrobiell katalysierter Redoxprozesseauf die Enntwicklung der Sicker-und Grundwasserqualität in den Kippenmassiven des Lustizer Braunkohlereviers. In: Krzaklewski (Ed.) Górnictwo 
odkrywkowe - Środowisko - Rekultywacja zeszczególnym uwzględnieniem KWB „Bełchatów”. Drukrol, Kraków, 5-19.

6. Krzaklewski W., Kowalik S., Wójcik J. 1997. Rekultywacja utworów toksycznie kwaśnych w górnictwie węgla brunatnego. Monografia, Monos, Kraków.

7. Polak K., Galiniak G. 2007. Wstępna ocena podatności zbiornika poeksploatacyjnego Pątnów na degradację. Górnictwo Odkrywkowe, 5-6, 181-185.

8. Ratajczak T., Bahranowski K., Górniak K., Szydłak T., Wyszomirski P. 1995. Kopaliny towarzyszące. [In:] Stryszewski M. (Ed.) Eksploatacja selektywna węgla brunatnego i kopalin towarzyszących wraz z uwarunkowaniami techniczno-ekonomicznymi i korzyściami ekologicznymi, 45-74.

9. Rozporządzenie Ministra Środowiska z dnia 9 września w sprawie standardów jakości gleby oraz standardów jakości ziemi. (Dz. U. 2002 Nr 165, poz. 1352)

10. Różkowski K., Polak K., Cała M. 2010. Wybrane problemy związane $\mathrm{z}$ rekultywacją wyrobisk $\mathrm{W}$ kierunku wodnym. Górnictwo i Geoinżynieria, 4, 517-524.
11. Schulze M., Boehrer B., Kuehn B. and Büttner O. 2002. Neutralisation of acidic mining lakes with river water. Verh. Intern. Verein. Limnol., 28, 936-936.

12. Schulze M., Boehrer B., Duffek A., Herzsprung P., and Geller W. 2005. Introduction of river water as a tool to manage water quality in pit lakes. In: Loredo J. and Pendas F. (Eds.) Proceedings of thde $9^{\text {th }}$ International Mine Water Association Congress. 273-279.

13. Siera W. 2012. Zbiorniki poeksoploatacyjne Przykona, Janiszew, Bogdałów. Sesja naukowa „Bioróżnorodność terenów pokopalnianych rejonu konińskiego". Muzeum Okręgowe w Koninie, 93-105.

14. Skawina T., Zubikowska-Skawinowa 1964. Zagadnienia toksyczności i neutralizacji na rekultywowanych zwałowiskach KWB ,Turów”. Węgiel Brunatny, 2, 135-142,.

15. Spychalski W., Gilewska M., Otremba K. 2008. Uziarnienie i skład chemiczny gleby wytworzonej z gruntów pogórniczych KWB „Konin”. Roczniki Gleboznawcze, Vol. LIX, No. 2, 207-214.

16. Staniszewski R., Jusik Sz. 2013. Wpływ zrzrutu wód kopalnianych z odkrywki węgla brunatnego na jakość wód rzecznych. Rocznik Ochrona Środowiska, 15, 2652-2665, . 